\title{
再突入宇宙機のための高速風洞試験と模型表面可視化法*
}

\author{
鈴木宏二郎 ${ }^{* *}$ ，綿賁 忠晴***，久保田弘敏***
}

\section{Surface Visualization Methods at High Speed Wind Tunnel Testing for Reentry Vehicle}

Kojiro SuzuKI, Tadaharu WatanukI and Hirotoshi KuBOTA

\section{1. まえがき}

多様化する宇宙環境利用や宇宙科学探查において, 創 成された新材料や探査した天体の土壤サンプルなどその 成果を地上に持ち帰るための再突入宇宙機の開発は我が 国の宇宙開発のキーテクノロジーのひとつである.この ような宇宙機では, 大気突入飛行時の機体周りの高速気 流に関する理解が重要である事は言うまでもない. その 際に，機体の空力特性と並んで極超音速飛行に伴う空力 加熱の問題がある．空力加熱量の尒測を甘くして宇宙機 とそのペイロードを危険に曝す事はできないが, かと 言って過大な耐熱シールドを取り付ける事は重量制限の 厳しい宇宙機において受け入れられない、そこで再突入 宇宙機の空力加熱率の正確な予湘が必要となるが, それ を難しくしている問題が 2 つる.ひとつは、高温衝撃 層流れと機体耐熱シールドとの熱化学反応であり，もう ひとつは機体表面上の境界層における乱流遷移である.

地球周回軌道からの再突入カプセル体の場合, 高度が $50 \mathrm{~km}$ 以下となると $1 \mathrm{~m}$ あたりのレイノルズ数が $10^{5}$ を 超え機体表面の一部で乱流遷移が起こる可能性がある.

一方，機速は大気突入速度からあまり減速しておらず空 力加熱が厳しい領域にある.図 1 は乱流遷移を想定した 場合の空力加熱率分布の推算例である ${ }^{11}$. 鈍頭部で乱流 遷移が起れば最大加熱率は淀み点ではなく遷移点直後と なる可能性がある．後方のスカート部で遷移が起った場 合でも，その部分の表面積が大きいだけに耐熱シールド の追加は大きな重量増となりうる.さらに,アブレーショ ン熱防御系の場合, 空力加熱による樹脂の熱分解や表面 の化学反応 (酸化, 昇華) で発生したガスが境界層内に 噴き出し, その干涉効果によって乱流遷移を促進すると 言った複合作用の可能性もある゙2.いずれにせよ機体表 面で乱流遷移が起れば，壁面加熱率は大幅に増加するた め，それを想定した上で耐熱シールドの設計をしなけれ ばならない、残念ながら，このような高速流における乱 流遷移現象はその重要性にもかかわらずほとんど分かっ ていないのが現状である。まずは，現象を理解すると言

* 原稿受付 1998 年 1 月 5 日

** 東京大学大学院工学系研究科 航空宇宙工学專攻

*** 正会員 東京大学大学院工学系研究科 航空宇宙工学専攻

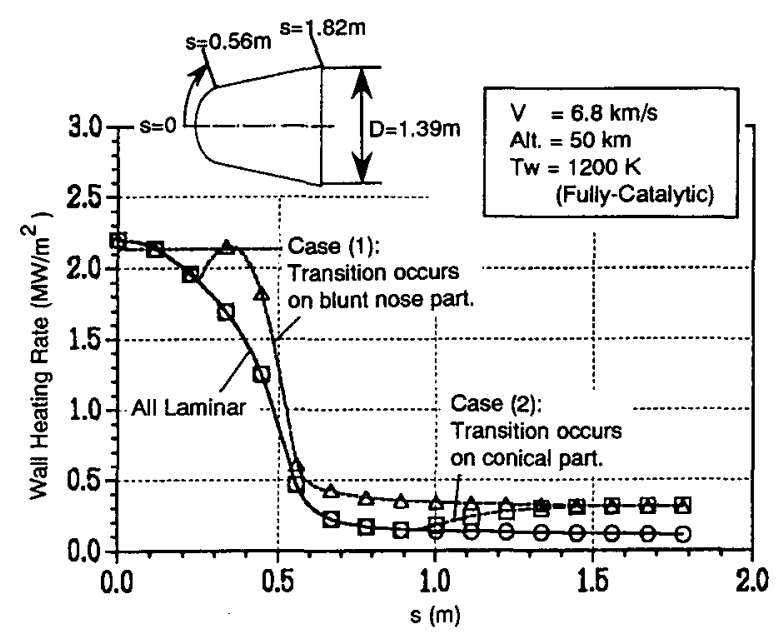

図 1 乱流遷移と壁面加熱率の増大

う点で乱流遷移を見る（可視化する）事から始めねばな らない.

このような背景から筆者らは再突入鈍頭カプセル形状 について高速風洞を用い, チャイナクレイ法と赤外線画 像法による境界層乱流遷移の可視化, 油膜法による表面 摩擦力線の可視化, 感温塗料による模型表面温度可視化 に関する実験を行ってきた，本稿ではこれらの可視化実 験とその結果を中心に紹介する. 高速風洞とは言え, こ こで扱うマッハ数は最大でも 7 であり再突入飛行体の実 飛行環境をシミュレートしたものにはなっていない。あ くまで「マッハ数を高くして行った場合の傾向を見る」 のが目的である. 今後, 風洞設備も含め高エンタルピー 流れにおける地上実験法のさらなる発展が望まれるとこ ろである。

\section{2. 高速風洞における流れの可視化の問題点}

高速風洞において可視化実験を行う際の問題点として はまず：

・限られた視野

・通風開始時および終了時の衝撃流れ

・限られた通風時間

が挙げられる。

通常の風洞では模型支持装置と天秤による空気力の測 定を第一とし, 可視化実験のための設備としてはシュ 
リーレン法のための空と光源／光学系程度であるものが 多い. 測定部の中にある模型への投光や撮影は全てシュ リーレン空を通して行わなければならない. 従って鈍頭 物体淀み点近傍や翼前縁などを視野に入れるのが困難と なる. 視野に入っても斜め方向からとなるため, 複数の 角度から画像を取得し計算機の中で合成する ${ }^{3)}$ と言った 高価なシステムとしない限り, 定量評価の対象となるよ うな精度の良い画像を得るのは難しい. 模型側面の画像 を撮る場合でも投光が斜めとなるために, 明るさが不均 一になったり, 模型表面にハイライトができたり, 空か らの反射光が入ったりとその調節には注意が必要である。

超音速風洞や極超音速風洞では通風開始時と終了時に 非定常衝撃流れを伴う. 油膜法やチャイナクレイ法など の模型表面のパターンもその際に崩れてしまう可能性が ある. 従って撮影は通風中に終了しておく必要があるが, 観測空からの限られた視野では観測したい全ての角度か らの画像を得るのは困難である. また, 極超音速風洞で

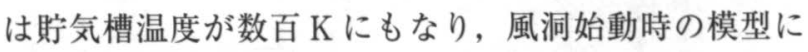
対する熱負荷が大きい. 表面温度の可視化を行うため熱 伝導性の低いセラミックなどの材料を模型に用いた場合, 熱的衝撃により模型の破損を招く事がある.これは模型 の製作法に関する事で可視化法とは直接関係がないが案 外このような事でも実験は手こずるものである.

高速風洞では一般に通風時間が限られているのでその 範囲内で実験を終了させなければならない. 油膜法のよ うにそのパターンに初期状態への依存性がなくなり定常 状態に落ち着くまで時間がかかるものは, それを計算に 入れて風洞運転計画を立てなければならない.

\section{3 ，超音速風洞における表面流れの可視化法}

本節では超音速風洞における再突入カプセル体表面流 れの可視化について述べる.ここで紹介する結果は全て 宇宙科学研究所高速気流試験設備を用いたものである. 最大マッハ数は 4 であり, 貯気槽は常温であるため一様 流静温は室温より低い. 模型表面の温度は通風中に若干 冷却される程度でほとんど室温に近いと考えられる. 可 視化実験の目的は第 1 節でも述べたように鈍頭カプセル 形状における境界層遷移とマッハ数の関係を知る事であ る.

\section{1 油膜法による表面摩擦力線の可視化}

流れが高温にならない限り、低速風洞で用いるのと同 様な方法で油膜法の表面パターンを得ることができる. 即ち酸化チタンをオレイン酸で溶き, 必要に応じて流動 パラフィンで延ばしてオイルの固さを調節する. オイル は白い液体であり，あらかじめ黒く塗装した模型表面に 筆で塗付する. 通風開始時の衝撃で大部分のオイルが飛 散するが残ったものが表面摩擦力ベクトルに従い表面上 にパターンを形成する. 流れの条件やオイルの固さにも よるが, 少なくとも 10 秒以上気流に曝さないとオイル の塗り方や通風開始の衝撃の影響が消えずパターンの解
釈で誤解する恐れがある. 図 2 にマッハ数 4.0 における 鈍頭円錐体の油膜法可視化例を示す. 鈍頭部と円錐部の 接合部下流にオイルの堆積が見られ表面摩擦力の非常に 弱い領域があるのがわかる. その下流で表面摩擦力が回 復しオイルが掻き出されているが, 鈍頭部に比べ表面摩 擦力が弱くオイルが白く残っている. なお, 図中央に見 える楔状のパターンは風洞中のダストの衝突によって模 型に生じた傷によるものである. 鈍頭部と円錐部の接合 部では表面の曲率が不連続に変化しており, 円錐部での 遠心力の消滅が壁面上での逆圧力勾配を生み局所的な剥 離 ·再付着を生じさせていると考えられる. 同様な結果 は OREX 再突入飛行体の超音速風洞実験でも報告され ている4).ただし,「オイルの堆積」が常に「逆流域を伴 う剥離の存在」を意味するとは言い切れず, 表面摩擦が 弱いためオイルの掻き出しが遅れているだけと言う可能 性もある. さらに、オイルの過大な堆積は衝撃波を形成 し本来の流れ場を変えてしまっている可能性もあるので 注意を要する.

境界層乱流遷移は表面摩擦力の急増を伴うため油膜法 のパターンにもその影響が現れる事がある. 図 2 で円錐 部後方にオイルを強く掻き出したようなパターンが見ら れるが, これは後述のチャイナクレイ法で遷移と判断さ れた場所（図３参照）に近い.しかし，一般には, 油膜 法の結果だけから遷移を判定する事は難しい.

\section{2 境界層遷移の可視化}

ここではチャイナクレイ法と赤外線画像法による境界 層遷移の可視化を紹介する.

(1)チャイナクレイ法

チャイナクレイ法 (蒸発法) は低速風洞実験において 乱流遷移を可視化する方法として一般的であるが, 高速 風洞でも模型温度が常温程度であれば全く同様に用いる 事ができる．これは層流境界層よりも乱流境界層の方が 模型表面での蒸発が速い事を利用したものである. 白陶

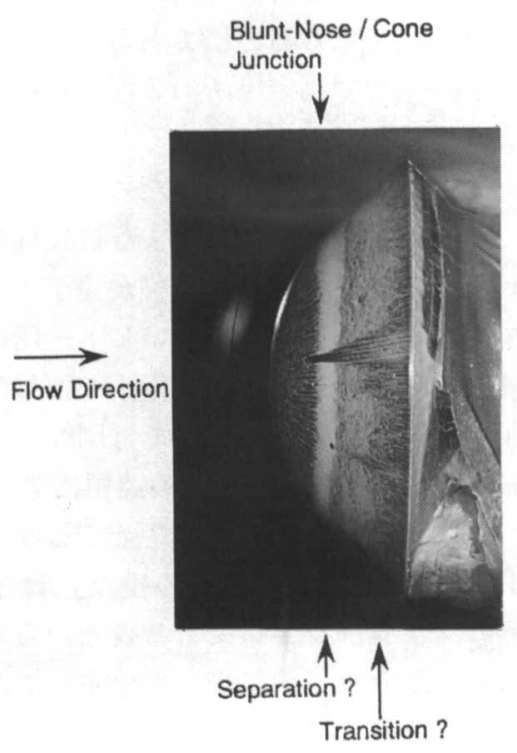

図 2 鈍頭円錐の油膜法による可視化例 

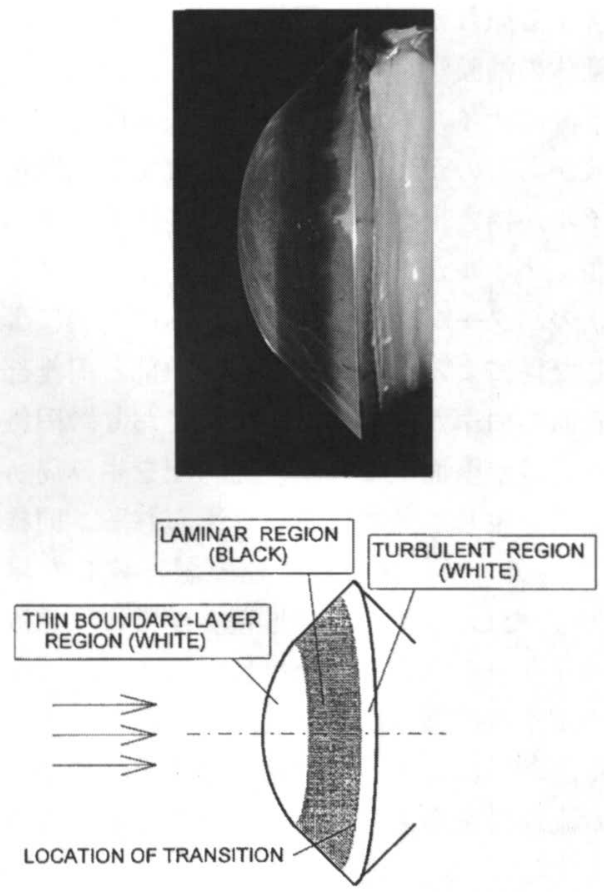

図３チャイナクレイ法によるパターンとその解釈

土（カオリン）を灯油で溶き予め黒く塗っておいた模型 にスプレーで塗付した後，通風を開始する．通風開始の 衝撃により表面の灯油は液滴となって飛散するが, 残っ た灯油は表面に薄く層を形成する．拡散の激しい乱流境 界層の部分は灯油の乾燥が早く，中に含まれる陶土が白 く浮き出てくる. 乾燥していない部分は模型の黒い地肌 が見えるため, 黒い部分を層流域, 白い部分を乱流域, その境界を遷移と判定する. 図 3 に図 2 と同一条件での チャイナクレイ法による可視化結果とその解釈を示す.

まず，高速風洞におけるチャイナクレイ法の妥当性を 確認するため行った表面ピトー圧トラバース法との結果 の比較について紹介する. 表面ピト一圧法 ${ }^{5)}$ とは図 4 の ように径の細い（境界層厚さより細いもの）ピトー管を 表面に接触させた状態で流れ方向にトラバースし，その 変化から遷移領域を求める方法である. ピトー管は表面 に常に接しているので測定場所の表面からの高さは常に 一定である，下流にトラバースすると相対的に境界層底 部のピトー圧を測定する事になるため, その值は次第に 下がっていく，遷移が起ると図のように速度分布が変化 するためピトー圧が上昇する．遷移が完了すると下流方 向に乱流境界層が厚みを増すに従いピトー圧は再び減少 する. 図 4 において、ピトー圧の極小を遷移開始，極大 を遷移完了と判断している.ここでは図 3 のチャイナク レイ写真に示された半頂角 45 度の鈍頭円錐における結 果を示す ${ }^{6)}$. マッハ数は 4.0 , 底面直径でとった主流レイ ノルズ数は $2.4 \times 10^{6}$ である.この模型には第 1 節でも 触れたようにアブレーションによる表面からの噴き出し を模擬するため淀み点領域に細孔が分布しており，そこ から噴き出しを与える事ができるようになっている．図 5 に表面ピトー圧法とチャイナクレイ法から得られた遷
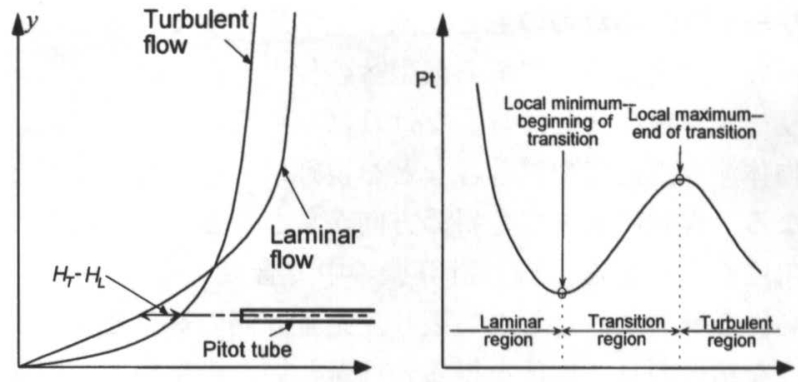

図 4 表面ピトー圧法と境界層遷移の判定 ${ }^{5)}$

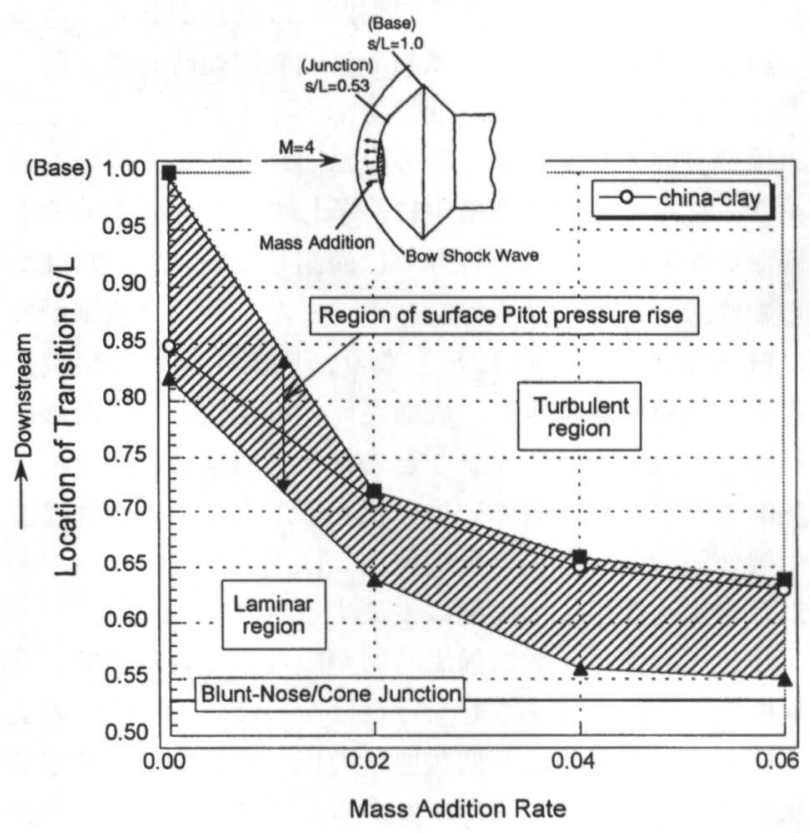

図 5 チャイナクレイ法と表面ピトー圧法による 境界層遷移位置の比較

移位置の比較を示す，横軸は主流流束に対する噴き出し の強さである，噴き出しによって境界層遷移が促進され その位置が前進するのがわかる，チャイナクレイ法によ る遷移位置は, 表面ピトー圧法によって求められる遷移 領域（図中の斜線領域）の中に入っており両者の結果に 矛盾がない事がわかる. しかし，チャイナクレイ法が遷 移領域のどの部分を捉えて図 3 のような境界線を形成す るのかはわかっていない.

図 6 (a)-(c)に半頂角 11 度の鈍頭円錐のマッハ数 1.5，2.0，3.0における可視化結果を示す ${ }^{7)}$. 迎角は 0 度で、模型底面直径でとった主流レイノルズ数は 1.5 $3.0 \times 10^{6}$ である. マッ八数が大きくなる程, 遷移位置が 後退しており,「マッハ数が高くなるほど遷移しにくく なる」と言う一般則 ${ }^{8)}$ と一致している. なお, マッハ 数 3.0 (図6(c)) において見られる孤立した楔上のパター ンは風洞中の夕スト衝突による模型の傷から生じた乱れ である．模型は迎角 0 度の軸対称であるが遷移位置は軸 対称ではなく, 周方向に波形のパターンを形成する事が ある.この場合, マッハ 1.5 以上では楔状の領域が周方 向に並ぶ. 楔の間隔はマッハ数が高くなる程大きくなる. 
(a)マッハ数 1.5

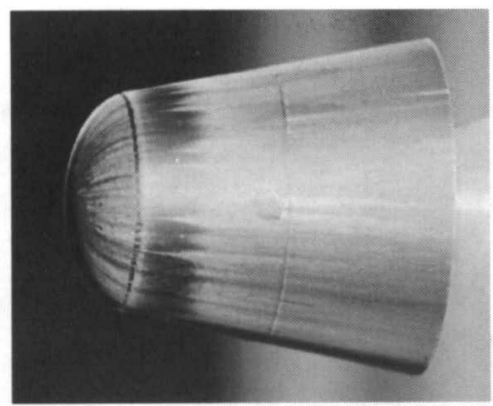

(b)マッハ数 2.0

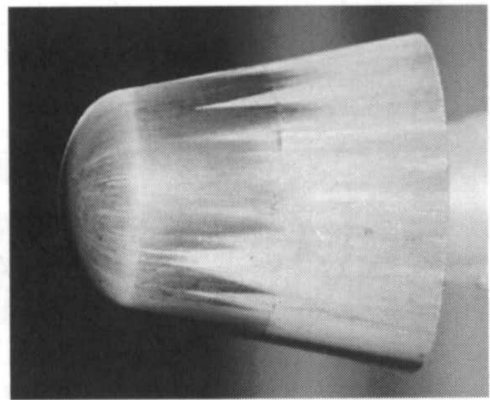

(c)マッハ数 3.0

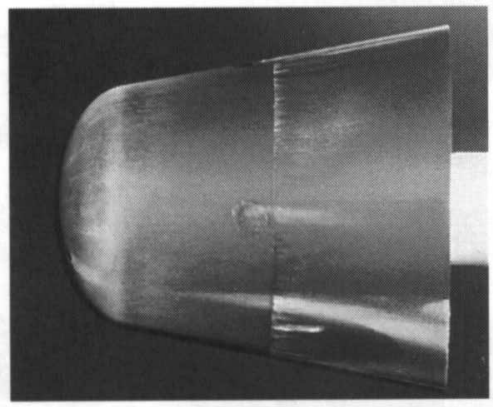

図 6 鈍頭円錐体における乱流遷移とマッハ数の影響 (チャイナクレイ法による可視化 ${ }^{7}$

白い乾燥領域が出始める部分を遷移開始とし, 全周が白 くなる位置を遷移完了と考えると図の結果は，「マッハ 数が大きいと遷移完了までに距離がかかる」と読み取れ る.

チャイナクレイ法は専用の実験模型や特殊な光学系を 必要としないため, 高速風洞においても便利な境界層遷 移可視化法ではあるが実際の適用において以下のような 問題点がある.

・高速風洞では測定部を閉じてから通風開始までに時間 がかかる事があるため，その間に灯油が乾燥してしまわ ないよう注意する。また, 油膜法と同様, 通風終了時の 衝撃で表面のパターンが崩れてしまうので, 画像の取得 は通風中に済ませる必要がある.

・一般にマッハ数が高くなると遷移開始から遷移完了ま での距離がかかるようになり遷移を領域で捉える必要性 が出てくる. チャイナクレイ法では灯油の未乾燥領域と 乾燥領域の 2 者しか区別ができないため, その境界が遷 移領域のどの部分に相当しているのかが不明である.

・チャイナクレイ法では、乱流境界層領域のみならず、 境界層の薄い前縁部でも乾燥が速い. 鈍頭カプセル形状
の場合, 図 3 のように鈍頭部の全面が白くなってしまう ので, 乱流遷移の判定が行えるのはその下流部のみとな る.

・チャイナクレイ法は層流と乱流での灯油乾燥速度の差 を利用したものであるが、同時に灯油は表面摩擦力に よって表面上を流されている，流されながら乾燥して 残ったパターンが遷移の解釈を難しくする事がある.

・灯油が乾燥して残った陶土は模型表面にラフネスを与 え，本来の遷移位置を変えてしまう恐れがある.

図 6 では遷移位置が比較的明確に示されていたが，一 般に高速風洞ではチャイナクレイのパターンが不鮮明と なり遷移の判定が困難になる傾向がある. 図 7 は半頂角 10 度の球頭円錐のマッハ 2 における結果例であるが, 遷移と判定される境界線が 2 種類見えている. 遷移が 2 度に分けて段階的に起るとは考えにくくどちらかが誤っ た表示と言う事になる. その判定は他の方法との比較に よるしかない.この場合, 後述の赤外線画像法との比較 により上流側の境界が遷移であると判定された ${ }^{9)}$. 下流 側の線は、通風開始時に表面を灯油が流れた跡と考えら れている.このようなパターンは高速風洞におけるチャ イナクレイ法にしばしば見られ, その解釈に悩まされる. 模型表面上に剥離領域がある場合, 油膜法と同様に灯油 が堆積するため乾燥が起りにくい，そのため剥離域が層 流か乱流かの判定は困難である.さらに堆積した灯油が 通風中に液滴となり模型表面を移動し, 表面のパターン を崩し遷移の解釈を困難にする事もあるので注意を要す る.また，模型上に衝撃波ができている場合，衝撃波に 伴う温度や圧力の変化が表面の乾燥にどのように影響す るかについても考慮するべきであろう。

(2)赤外線画像法

層流境界層と乱流境界層の差は，模型壁面に対する熱 流束の差にも表われる. 貯気槽を加熱していない風洞の 場合, 模型周りの流れの静温は模型表面温度より低くな り模型を冷却する. 乱流領域では模型の冷却が層流領域 より激しくなるため, 遷移領域を境にその下流では模型 表面温度が急激に下がる事になる．従って，模型表面温

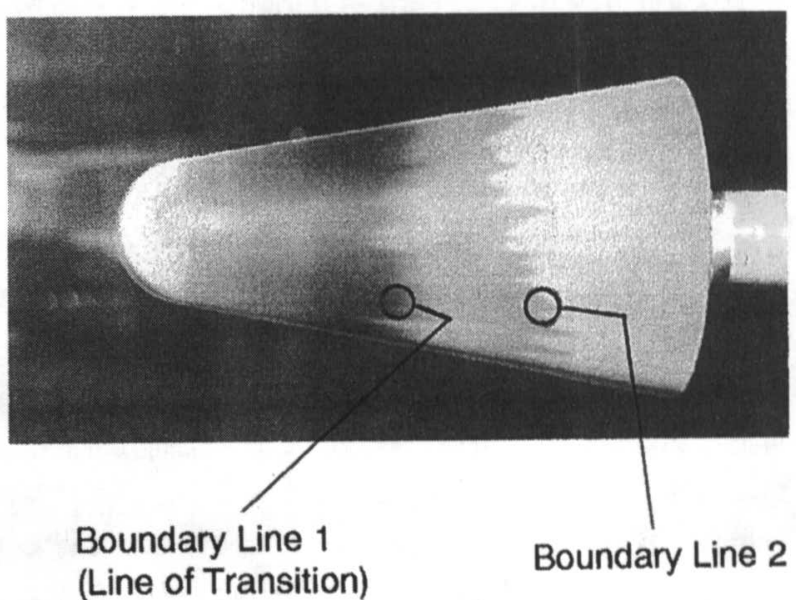

図 7 チャイナクレイ法に現れた 2 重模様 9 
度分布がわかれば遷移位置を知る事ができる ${ }^{9,10)}$. 赤外 線ビデオカメラは, 物体からの放射輝度を測定する事で 物体表面の温度分布を画像として取得する事ができる. 赤外線画像法による可視化は非接触であり, チャイナク レイ法のように模型表面に何かを塗付する必要もないた め流れ場を乱す事がない．問題点としては：

・赤外線ビデオカメラが高価なシステムである事,

・測定部の空を赤外線透過性のものと交換する必要があ る事,

・遷移による表面温度の差を顕著にするためには樹脂や セラミックなど熱伝導性の悪い材料で模型を作る必要が ある事,

などが挙げられる.例として図 8(a)に半頂角 10 度の球 頭円錐のマッハ 2.5 に㧍ける赤外線画像を示す9.10). 模 型底面の直径でとった主流レイノルズ数は $2.5 \times 10^{6}$ で ある。模型は樹脂（DELRIN）で作られている. 図8(b) にはある周位置での母線に沿った温度分布も示されてい る.鈍頭部から円錐部を下流に行くに従い表面温度が緩 やかに上昇しているが，これは境界層が厚くなり層流冷 却率が下がって行くためである. 円錐部中央付近で表面 温度が低下しているのは, 乱流遷移により表面冷却率が 増加したためであり，この部分が乱流遷移と考えられる。 このように赤外線画像法では遷移が領域として捉えられ る. 図8(c)にチャイナクレイ法による結果を示す。迎角 0 度の軸対称形状のため周方向にパターンの自由度があ るが, 遷移の位置に関しては, チャイナクレイ法と赤外 線画像法との差は殆どない. なお，チャイナクレイ法の 方が赤外線画像法よりわずかに上流側で遷移を示す事が あるが，これは塗付した灯油と陶土が模型表面に対しラ フネスとして働いたためと考えられている. 赫外線画像 法は高速風洞試験で一般に用いられるステンレス製模型 に対しても有効である.ただし，ステンレス製模型では 樹脂製模型に比べ内部への熱伝導が良いため表面温度が 均一化され遷移による差が出にくく, 赤外線画像での遷 移位置はややぼやける傾向にある. なお, チャイナクレ イに関しては表面温度が下がりやすい樹脂模型より, 表 面温度が下がりにくく蒸発がより活発なステンレス模型 の方が鮮明なパターンを与えるようである ${ }^{9}$.

\section{4. 極超音速風洞における表面温度の可視化法}

極超音速風洞では気流の淀み点温度が高く、模型表面 を高温に加熱するのでチャイナクレイ法は使う事ができ ない. 表面温度の空間および時間変化を測定する事がで きれば壁面加熱率を求め, それから遷移を判定できる.

表面温度は熱電対をあらかじめ模型に取り付ければ測定 可能であるが, 測定位置は離散的であり空間分解能は低 い. 前節で紹介した赤外線ビデオカメラを用いれば空間 分解能の優れた表面温度分布デー夕を画像として得る事 ができるが, 必要器材の点で大がかりなものとなってし まう。ここでは，より簡単な感温塗料を用いた表面温度

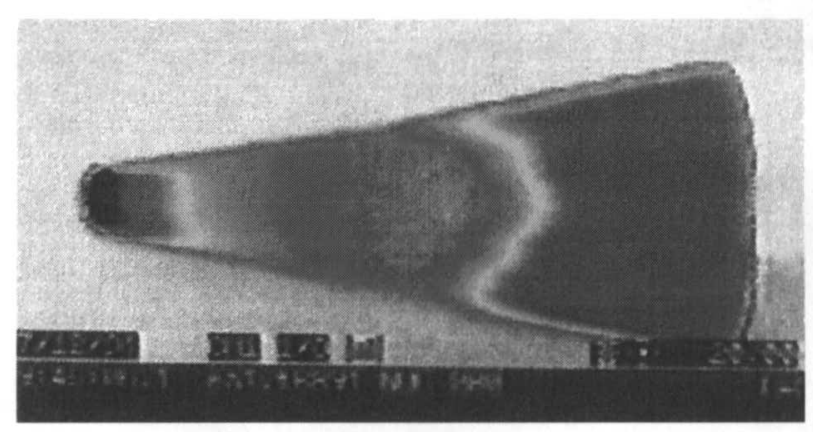

(a) 赤外線画像

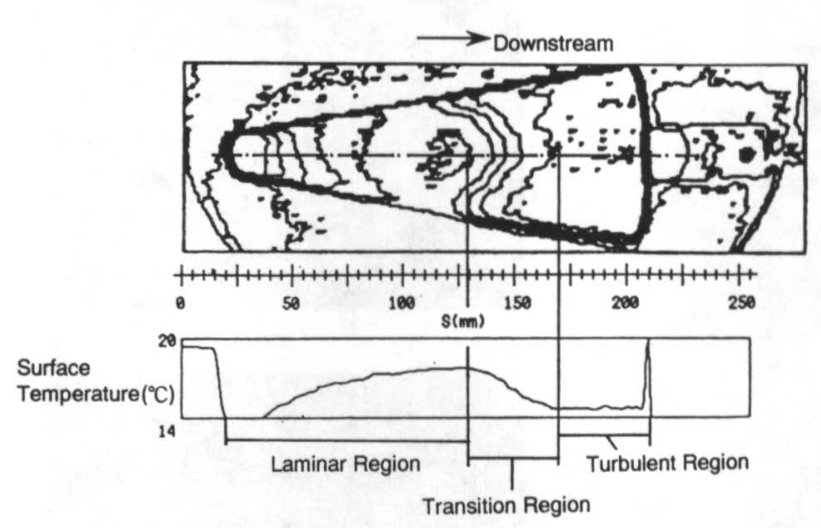

(b) 母線上表面温度分布

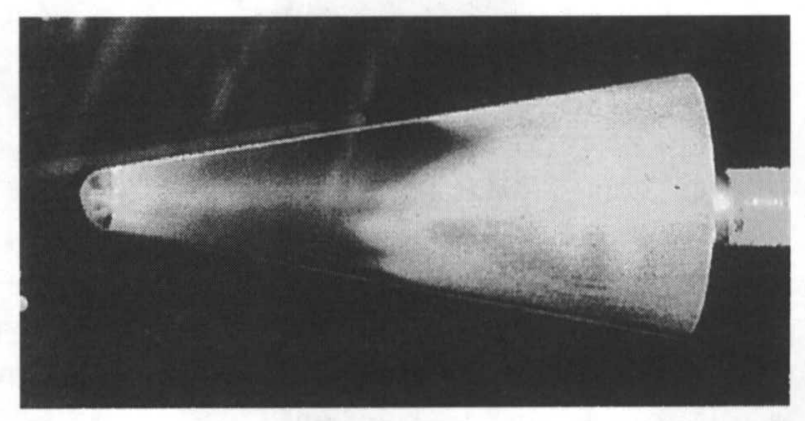

(c) チャイナクレイ法によるパターン

図 8 赤外線画像法による表面温度の可視化例 9.10$)$

の可視化法とその結果について紹介する ${ }^{11}$.

蛍光分子から出る光の放射強度は温度が高くなると弱 くなりいわゆる消光現象を示す. 感温塗料法はこの熱的 消光現象を利用して温度を計測するものである. 感温塗 料を塗った物体に紫外線を照射し, 励起された蛍光分子 からの放射強度を測定する．放射光は可視光であるため その強度はフィルターで紫外光をカットした上で CCD カメラに画像データとして記録される. 赤外線画像と異 なり, 取得するのは可視光であるため風洞の測定部は通 常のシュリーレン空でよく, センサーも一般的な CCD カメラが使えると言う利点を持つ.ただし, 模型表面へ の感温塗料の塗付が必要である.

損氏 $20 \sim 80$ 度の低温では塗料として有機物質が有効 であるが，極超音速風洞のように模型が高温となる場合 
は色素が熱で分解しないよう無機物質を使う必要がある. なかでも phosphorは繰り返しの加熱サイクルに対する 応答が安定している事, 模型表面に薄くコーティングで きる事から推奨されている11. phosphor はその種類に よって特性が異なるが, 測定温度範囲での温度感度が最 大になるよう選択する. 温度とのキャリブレーションは 相対放射強度に対して行われる. 相対放射強度とは, 測 定温度 $T$ での放射強度 $I(T)$ と参照温度 $T r$ での放射強 度 $I(T r)$ との比 $I(T) / I(T r)$ である. 参照温度は通風前 の状態という意味で常温とする事が多い. 相対放射強度 を用いる事により紫外線照射の非一様性や塗料コーティ ングの不均一性を結果から排除する事ができる. 図 9 に キャリブレーションの結果例 ${ }^{11}$ を示す. 用いた塗料は $L a_{2}$ $\mathrm{O}_{2} \mathrm{~S}: \mathrm{Eu}$ である. 図は繰り返し実験の結果がプロットさ れており, 480〜 $550 \mathrm{~K}$ の温度範囲において $5 \mathrm{~K}$ 程度の精 度で温度が繰り返し測定可能である事がわかる. それ以 下の温度になると放射強度の温度に対する感度が落ち測 定にばらつきが出やすくなる. 結果の精度は CCD カメ ラの精度にも依存しており, 勿論できるだけ高ビット数 の CCD カメラを用いるのが望ましい.

以下に東京大学工学系研究科の極超音速風洞で行った 実験結果例 ${ }^{11}$ を示す. 主流マッハ数は 7.0 , 模型底面の 直径でとった主流レイノルズ数は $4 \times 10^{5}$, 淀み点温度は $770 \mathrm{~K}$ である. 模型は壁面温度を上げるため熱伝導性の 悪いセラミックを用いている. 図 10 に半頂角 20 度の円 錐模型にトリッピングワイヤを巻いた時の模型表面から の CCD 画像を示す. トリッピングワイヤ下流で放射光 (赤色) が弱くなっているのがわかる.これはワイヤ下 流で乱流遷移が起り, 壁面加熱率の急上昇とともに壁面 温度も上がったためである. 表面温度分布から壁面加熱 率分布への変換は, 近似的には, 半無限長スラブを仮定

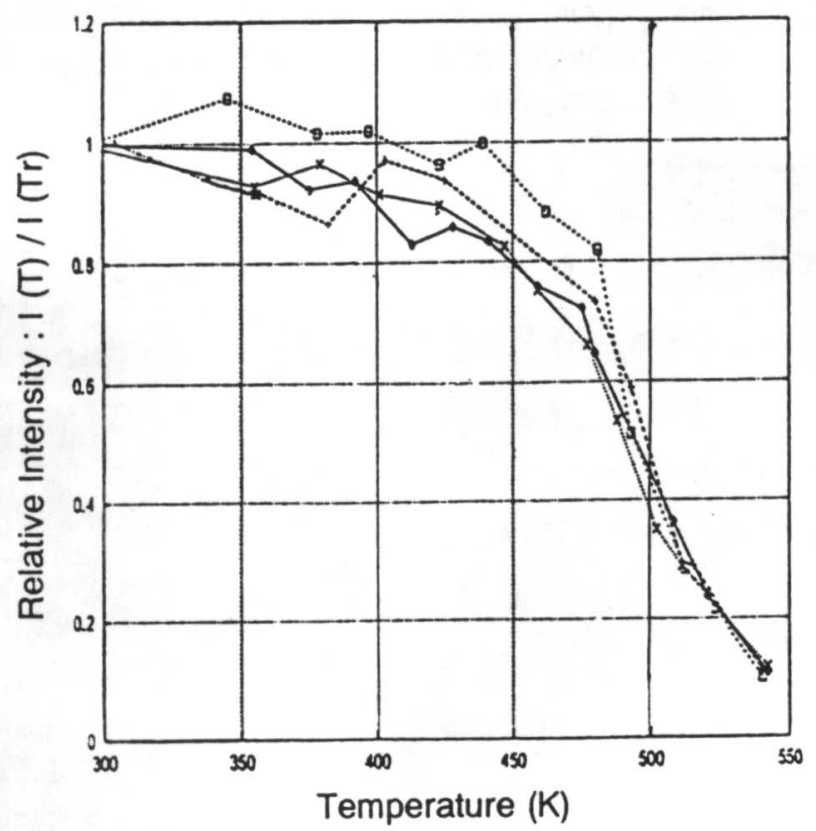

図 9 感温塗料 $\left(\mathrm{La}_{2} \mathrm{O}_{2} \mathrm{~S}: \mathrm{Eu}\right)$ の温度較正結果例 ${ }^{11}$
し壁から垂直方向に非定常 1 次元熱伝導方程式を解く事 でなされる. 図 11 にトリッピングワイヤ下流での壁面 加熱率分布を示す. トリッピングワイヤがない場合と比 較すると, ワイヤ下流で乱流遷移が起り加熱率が上昇し て約 $7 \mathrm{~mm}$ 後方でピークに達しているのがわかる. しか し実際の模型内部の熱伝導は複雑であり, 温度から加熱 率への変換に際して内部熱伝導モデルによる誤差を生じ る可能性もあるので, 定量的な評価の際には注意を要す る.

感温塗料による表面温度可視化の問題点としては：

・通風中の壁面加熱および気流中のダストなどにより塗 料コーティングが損傷し結果に誤差を生ずる事,

·このことは空力加熱の観点から重要である淀み点領域 で顕著な事,

・限られた風洞測定部空から淀み点を視野に入れるのが 困難である事,

・紫外線光の入射角が大きくなると放射強度が減り精度 が落ちるため, 風洞測定部空を通して入射光とカメラ視 野の両方の配置をうまく調整する必要がある事,
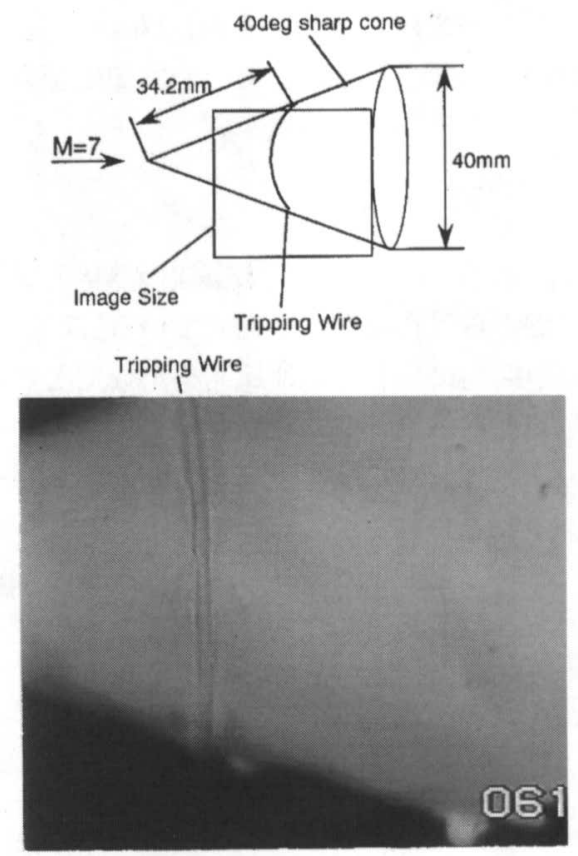

Tripping Wire

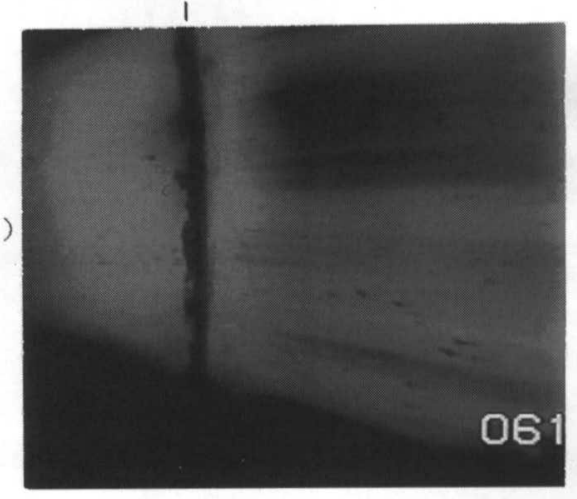

図 10 トリッピイングワイヤによる円錐上境界層の 乱流遷移 (感温塗料による可視化画像 ${ }^{11}$ 


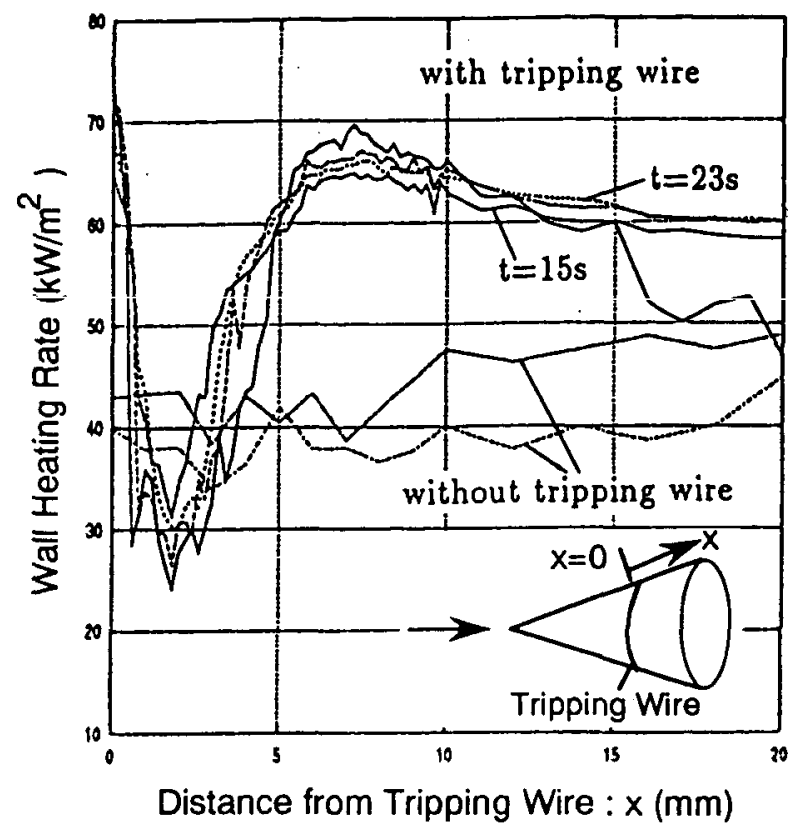

图11 トリピインダワイヤによる円錐上境界層の乱流遷移 (図 10 を画像処理して求めた壁面加熱率分布) ${ }^{11}$

などが挙げられる。また，図 $11 に$ 見られたような結果 のノイズを取り除くための画像処理方法なども今後の課 題であろう。

\section{5.おわりに}

本稿では, 再突入宇宙機の熱空力環境の予測という観 点から現在最も頭を痛めている「高速流での境界層遷移」 の問題に対し，高速風洞を用いてどのような可視化法が 使えるか筆者らの経験を中心に紹介した。これらの手法 はどれも流れ場の現象を比較的ストレートに見ているも のと思われるが，「流れの何を見た事になったのか」に ついて詳細な議論をしようとすると案外あやふやな所が あるのに気づく．油膜法やチャイナクレイ法などは一種 の気液二相流であるから，ここでひとつ近年発達が著し い数值流体力学（CFD）の力を借りて「可視化法のダ
イナミクス」を見值してみるのはどうであろうか．

本稿をまとめるにあたり, 赤外線画像法については東 京大学工学系研究科航空宇宙工学専攻博士課程大学院生 の松浦一哲君, 表面ピトー圧法とチャイナクレイ法の比 較に関しては同修士課程の大坪武史君，感温塗料につい ては同じく安田篤君の研究成果に負う所が大きい.ここ に感謝の意を表する。

\section{参考文献}

1）鈴木宏二郎, 安部隆士：再突入回収カプセル体衝撃層の熱空 力環境に対する乱流遷移の影響, 平成 4 年度宇宙航行の力学 シンポジウム (1992) pp. 50-55

2) Park, C.: Injection-Induced Turbulence in Stagnation-Point Boundary Layers, AIAA J., Vol. 22, No. 2 (1984) pp. 219-225

3 ）吉澤昭, 井上安敏, 山本行光, 駒徹郎：IR サーモグラフィに 上る空力加熱分布の定量测定, 第 34 回飛行機シンポジウム 講演集 (1996) pp. 121-124

4) 野田順一, 楯篤志, 渡辺光則, 浜本滋, 原亘利, 吉永崇: 力 プセル形状の軌道再突入実験機模型の前面に表れるリング模 様, 第 28 回流体力学講演会講演集 (1996) pp. 253-256

5 ）石田洋治, 野口正芳: 可視化法および表面ピトー圧法による 遷移点測定と理論值との比較, 流れの可視化, Vol. 6, No. 20 (1986) pp. 73-81

6 ) 大坪武史, 安世滂, 鈴木宏二郎, 木鄉素行, 安部隆士: 表面 噴き出しのある鈍頭物体の超音速に扔ける乱流遷移の実験的 研究, 第 29 回流体力学講演会講演集 (1997) pp. 269-272

7 ) Suzuki, K. and Abe, T.: Experimental Studies on BoundaryLayer Transition on a Reentry Vehicle at Transonic and Supersonic Speeds, ISAS Report No. 659 (1995)

8 ) Anderson Jr., J. D.: Hypersonic and High Temperature Gas Dynamics, McGraw-Hill (1989) pp. 271-280

9）松浦一哲：超音速流中に抢ける軸対称物体の境界層遷移可視 化, 東京大学修士論文 (1994)

10）松浦一哲, 鈴木宏二郎, 本郷素行, 安部隆士：超音速流中で の軸対称物体の境界層遷移可視化, 第 26 回流体力学講演会 講演集 (1994) pp. 255-258

11）安田篤, 坂越中, 綿貫忠晴, 久保田弘敏：感温塗料を用いた 極超音速流中での熱伝達率の測定, 第 29 回流体力学講演会 講演集 (1997) pp. 9-12 


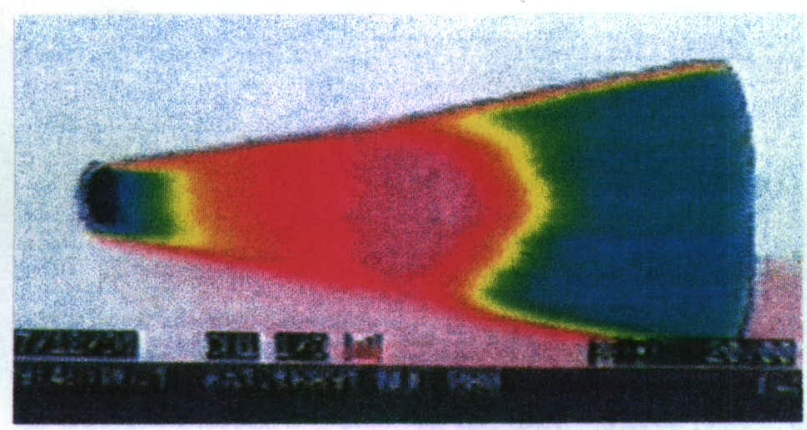

（a）赤外線画像

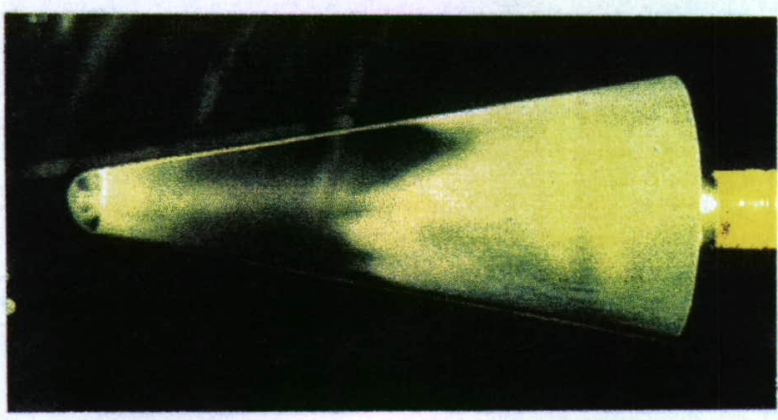

（c）チャイナクレイ法によるパターン

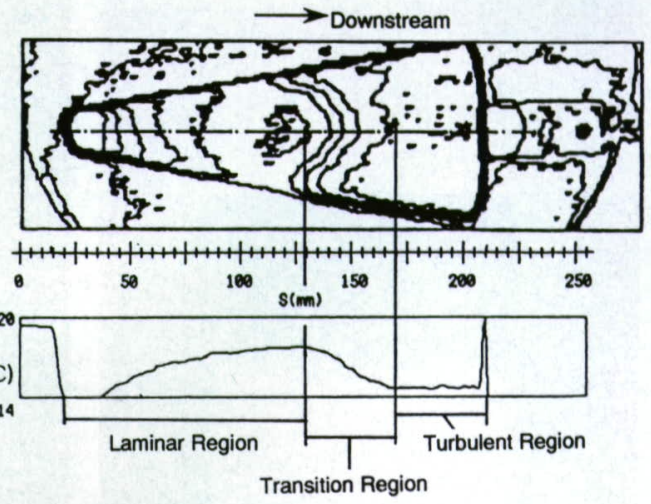

（b）母線上表面温度分布

口絵 7 赤外線画像法による表面温度の可視化例

(口絵 7 東京大学 鈴木宏二郎) (本文 110 頁参照)

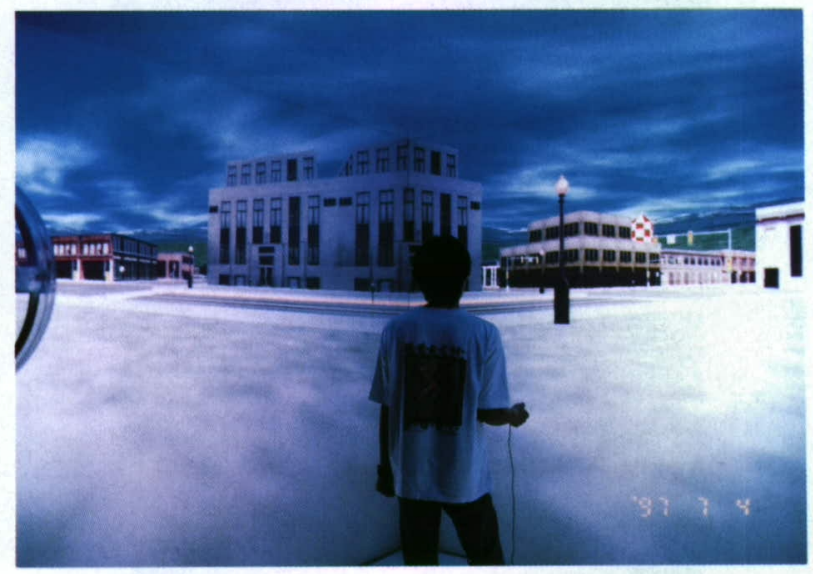

（a）CABIN を用いた仮想の街の体験

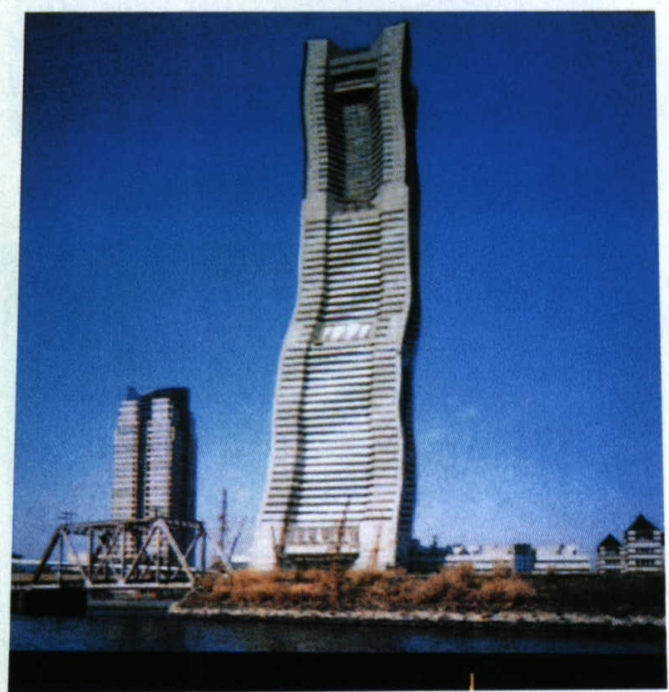

（b）実画像を用いた建物の地震応答解析の可視化

ロ絵 8 東京大学インテリジェント・モデリング・ラボラトリー

(口絵 8 東京大学 小木哲朗) (本文 149 頁参照) 